\title{
Inelocutio, Shakespeare, and the Rhetoric of the Passions
}

\section{Keir Elam}

\section{(2) OpenEdition}

\section{Journals}

\section{Electronic version}

URL: http://journals.openedition.org/shakespeare/1239

DOI: 10.4000/shakespeare.1239

ISSN: 2271-6424

\section{Publisher}

Société Française Shakespeare

\section{Printed version}

Date of publication: 1 November 1992

Number of pages: 143-156

\section{Electronic reference}

Keir Elam, «Inelocutio, Shakespeare, and the Rhetoric of the Passions », Actes des congrès de la Société française Shakespeare [Online], 10 | 1992, Online since 01 January 2007, connection on 04 May 2019.

URL : http://journals.openedition.org/shakespeare/1239; DOI : 10.4000/shakespeare.1239

This text was automatically generated on 4 May 2019.

(C) SFS 


\section{Inelocutio, Shakespeare, and the Rhetoric of the Passions}

Keir Elam 